\title{
The Theory of Multinational Enterprises: Revisiting Eclectic Paradigm and Uppsala Model
}

\author{
Ataul Kaium Chowdhury \\ MBA, Cardiff University, United Kingdom \\ E-mail: ataul.chy@gmail.com
}

Received: June 2, 2015 Accepted: June 15, 2015 Published: June 25, 2015

doi:10.5296/bmh.v3i1.7897 URL: http://dx.doi.org/10.5296/bmh.v3i1.7897

\begin{abstract}
Globalization has been evolving through the growing trend of multinational enterprises (MNE) for a prolonged period. In this fierce competitive market, corporations are trying to spread out their operations in different geographic locations in order to gain different advantages. Based on past literatures, the goal of this paper is to explain the relevant theories of multinational enterprise through proven theories and scholars viewpoint. With the theoretical ground of 'Uppsala model' - that explains the internationalization process and, 'Eclectic Paradigm' - that explore the factual reasons behind internationalization, this paper would focus on the rationale and process of becoming MNE. Additionally, with many critics' viewpoint, real life examples of successful MNEs, this paper found the foundations that embolden the new generation firms to spread its production and head office in different part of the world successfully as a process of turning into MNE.
\end{abstract}

Keywords: Multinational Enterprises, MNE, Uppsala model, Eclectic Paradigm, OLI Theory, Internationalization process 


\section{Introduction}

Multinational Enterprises are those companies, which have spread out its production and headquarter in more than one country (Maghrabi, 2006). Some writers have shown support to MNE, while others argue on the ruthless sides by focusing on its extreme domination power over economy. While many critics (Modelski, 1972; Dicken, 2003) clams that the MNE are the shaper of the global economy, Bhagwati (2004) have argued that multinationals are engaged in a 'race to the top', hence they are in the control of the economy. In contrast, Yeung's (2009) study shows robust evidence that multinationals is indisputably enhancing the developing country's economy.

Regardless of the arguments of different scholars, firms invest beyond their geographical boundary. Although the Uppsala model and the OLI theory has described the basic process and rationale of being MNE, as the time changes, new perspective has comes up and has added numerous dynamics into the whole issue.

\section{Methodology}

In order to scrutinize on MNE and outline the reason and process of becoming MNE, this paper has employed qualitative research approach where secondary research is deployed to explain the whole issue.

Based on Dunning's (1993) eclectic paradigm, the first portion of this paper will enlighten on advantage that a firm look forward in order to become MNE. The second half will scrutinise and illustrate the process that involved in an internalization process. Finally, with support of Uppsala Model of internalization, this paper would try to summarise the whole arguments fully based on proven literatures from prominent scholars.

In order to come up with the findings and agraphical model, Uppsala Model of Internationalization and Eclectic Paradigm along with slight touch of other prominent theories has been used.

\section{The Reasons to Become MNE}

There are number of reasons that attract firms to spread out its operations through internationalization these includes: low labour cost (Dunning, 1993), reduce distribution cost (Navaretti et al., 2005; Needle, 2010), obtain greater efficiency (Vernon, 1979), achieve 'better economy of scale', overcome trade barrier (Needle, 2010). Dunning (1993) has describe the reason for internationalization for the motives such as market-seeking, efficiency-seeking, asset-seeking and resource-seeking necessity of firms. These prominent issues entice firms to enter into foreign markets. Dunning's (1993) eclectic paradigm, which is also known as OLI theory, has presented the underling rationale for firms to become MNE in an integrated way. Dunning (1993; 2000; 2001) claims that availability of Ownership advantages, Locational advantages, Internalization advantages encourages firms to become a multinational. 


\subsection{Ownership Specific Advantage}

First of all, 'ownership specific advantage' basically means where a company enable to establish themselves with the help of their brand name, trade mark, superior production mechanism etc. (Dunning, 1993). Hsu and Pereira's (2008) study also shows that 'Ownership specific advantage' has been use as a significant issue in internalization; moreover, it can influence firms overall performance as well. An example could be Coca-Cola, which has very popular brand name that enables them to grab the market all over the world.

\subsection{Internalization Advantages}

Secondly, internalization advantages refer to the benefits that a firm may adopt the market more efficiently and keeping more control in overall strategies then entering the market through other firms or through exporting their products to secure the market (Dunning, 1993). He also argues that industries where $R \& D$ department plays a major role, for instance pharmaceutical companies, are mostly look forward to take advantages from the internalization. The multinational pharmaceutical industries in China, for example Novartis, Johnson \& Johnson etc., has start their endeavour with Joint Venture, consequently become fully multinational to retain the full control over $R \& D$, production and management decision (Medcof, 2006).

\subsection{Location-Specific Advantages}

Thirdly, location-specific advantages articulate to the benefits that a firm could achieve by launching full venture through FDI (Dunning, 1993). Hessels's (2008) imperial study has revealed that, location specific advantages may include availability of cheap labour, adequate resources of raw material in the targeted country. Ford Motor Company's project in India could be an example of location specific advantage. To capitalise on the ever-increasing demand of automobiles in the Indian automobile market, Ford has entered there through joint venture with Mahindra group. Accordingly, it has started its full business to capitalise the location specific advantages-for instant, utilising local resources, educating people and getting facility of low labour cost (Minter, 2009).

\subsection{Other Reasons that Encourages the New Generation Firms to Turn into MNE}

New generation firms, who have been facing even more challenge and competition, look for many other motivations to become MNE. Apart from Dunning's OLI theory some other critics has focused on couple of different aspects that might entice firms to become MNE. Many authors, such as Navaretti et al. (2005), argue against the common reasons that embolden small and medium firms to become multinationals. His study shows, relatively small and medium firms become MNE in order to spread their production and distribution cost in different countries. In support to this argument Vernon (1979) also claims that, firms main intention does not entirely depend on reducing cost, indeed, in numerous times they become MNE to compete efficiently in different market. Needle (2010) claim that economic recession in the home country, gaining economic of scale, to outperform the local competitors, develop transport and electronic communications are reasons for becoming MNE. In contrast, various researches showed the economic perspective of becoming 
multinational. For example, trade embargo, cost reduction pressure from suppliers might also be the reasons to enter into a foreign country (Doz, 1978; Needle, 2010). Doz's (1978) research shows that once a product come to its maturity stage, customers become price sensitive and hence suppliers put pressure to the manufactures to reduce price. This pressure could leads firms either to come up with innovative product or to set up production in different geographic location to grab different market.

\section{The Process of Becoming MNE}

The process that a firm go under while becoming MNE involved rigorous macro analysis that includes market size, economic status, government policy, labour market, and psychic distance etc. Carlson's (1966) cited in Forsgren and Hagström (n.d.) research revealed that when a firm find it too complex to market of foreign destination at the first place. 'Uppsala Model of internalization' could explain the predictability pattern of internalization process. According to Uppsala model of internalization, firm go through several processes that involves initially firm start acquiring knowledge from local market, then it starts exporting through autonomous agent and consequently it opens subsidiary or Joint venture as these are less risky (Johanson \& Vahlne, 2009). Vernon (1979) argued in his 'Product Life Cycle' theory that, when a firm see potential market in a foreign location it starts exporting to capitalize on the market; however in long term it could not be unsuccessful since local firms are cultured aware and could easily outplay the exporters. Hence to minimize those risk factors, finally firms open production plant and headquarter thus become multinational (Johanson \& Vahlne, 2009; Blomsterm \& Sharma, 2003).

\subsection{An Example of Internationalization Process: Toyota Motor Corporation}

The internationalization process of world famous car constructor Toyota could be used as an example to understand how a firm undergo various stages and become MNE. In 1963 Toyota start their internationalization process by starting export to Denmark (Toyota, n.d.; Doz, 1978). After getting initial exposure of European market, Toyota had opened its office in Belgium. In 1990s Toyota begins its production in Belgium and in 1993 it opens it European headquarter in Belgium. In 1994 to enter the Eurasian market, they established a joint venture with Mitsubishi in Turkey and consequently started manufacturing there from 2002. Thereafter, it has expanded its market in Poland, France, Czech Republic, Russia, and finally by opening global production centre in UK (Toyota, n.d.) and finally become a giant MNE.

Uppsala model also argues that firms initially go for nearest location as part of internalization assuming similarity in culture and business environment (Brewer, 2007). However many critics like Mtigwe (2006) cited in Guo and Upathamwaranon (2008) claim that the Uppsala is only handy for the initial stage of internationalization, hence it becomes obsolete in the end. Therefore, Uppsala model has been evolved in recent by emphasizing more in 'trust building' and 'relationship' unlike 'commitment' and 'activity' of the previous model (Johanson \& Vahlne, 2009). 


\section{1) Macrothink}

\section{Findings and Discussion}

From the qualitative analysis, based on different scholars like Dunning(1997), Johanson and Vahlne (2009), Navaretti et al. (2005) view on MNE, it could be claim that firms start the process of becoming multinational by exporting to its targeted country where potential market is available. After gaining knowledge, a firm start started to become stronger though JV or Greenfield partnership and ultimately start production and open headquarter to become operational on that location. Moreover, Toyota's internationalization example shows that Toyota had start exporting to Europe to gain knowledge about European market, culture, business strategies, than it become fully MNE. Again, Ford's example shows, how Ford has changed its mode of entrance in foreign market from exporting to JV due to government intervention in India, and successively develop its market in different location in the route of becoming multinational.

Moreover, as adequate theoretical evidence also reveals that if the firms follow the whole process they are most likely to be successful in their beyond the boarder venture as well. Hence, this is suggested that, firms that are looking forward to establish themselves as MNE should follow the structure discussed here to enhance the chance to be successful in their foreign venture.

\subsection{Internationalization Process: Graphical Representation}

Based on the discussion and analysis the below model has been developed, which shows the major process of Internationalization.

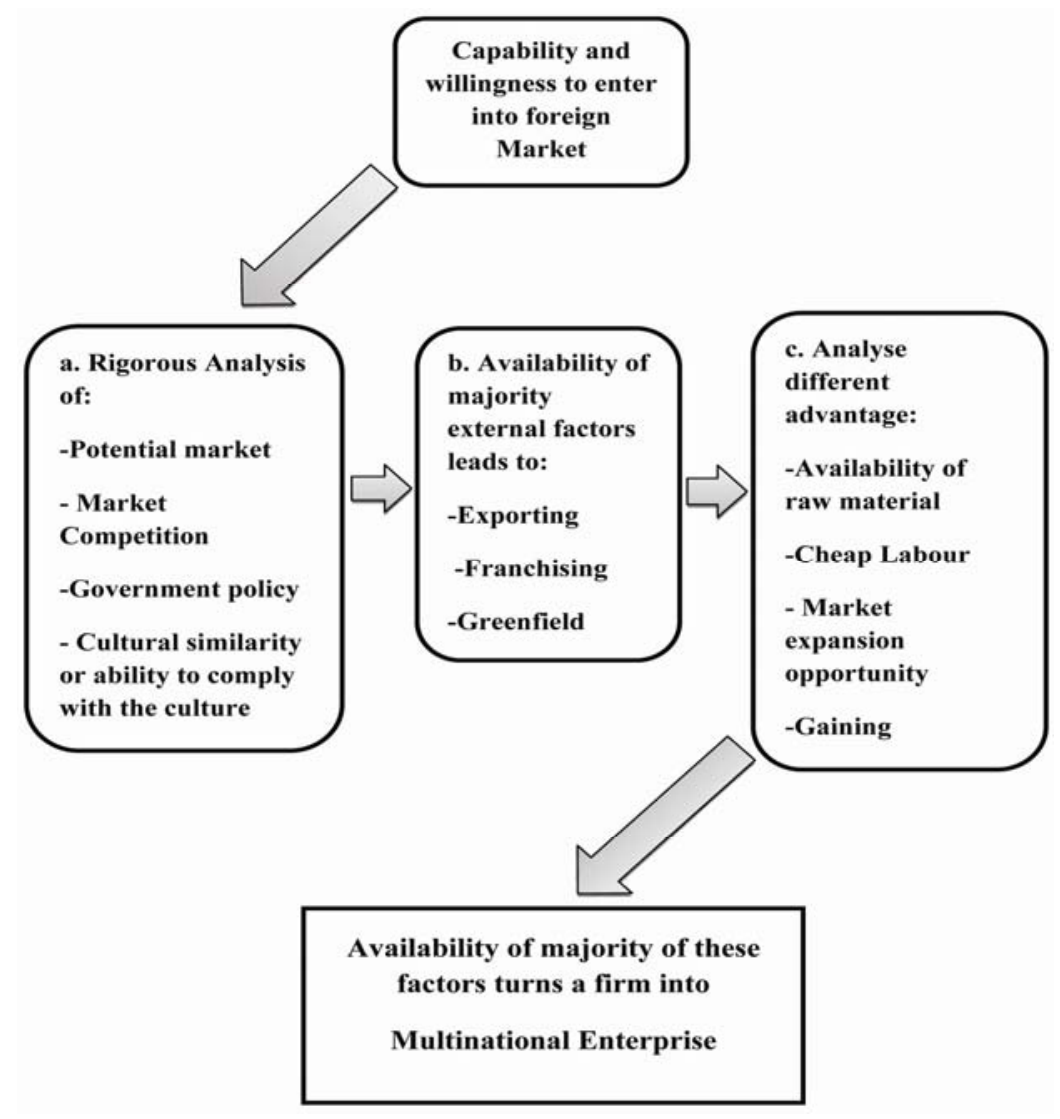




\subsection{Explanation of the Model}

The model illustrated above, articulates the main reason for becoming multinational along with the process that might involves in their internationalization process. At first, a firm gauge on whether firms have the capability to become a MNE. Consequently, once it finds that it has the capacity, firms intend to do a rigorous analysis on the macro environmental factors for instance- market opportunity, favourable government policy, cultural similarity. If their analysis comes with positive outcomes, a firm might go for exporting or form a joint venture in foreign location (Casson, 2000). Then thereafter, once they gathered adequate information on local market and have ample control on the resources, they focus on further research. Further analysis of location advantages that includes: cheap labour and availability of row material along with firm specific and internalization advantages, a firm finally decides upon whether to move the headquarter and production completely to that region and become an MNE (Dunning, 1997).

\section{Conclusion}

From the secondary research, description and from the diagram illustrated above suggest that emerging growth of global economy has created immense opportunity to grab global market. In contrast, it has created an extremely competitive market. In this borderless economy, firms are experiencing severe competition and numerous challenges to capitalize their footprint on the market of different territory. This makes firms to think in a global perspective and make the endeavour to become MNE in order to capture global market. Dunning's (1993) eclectic paradigm and Uppsala Model of internalization are the key literatures that has explained the reasons that encourage companies to go beyond the border and outlined its internationalization process.

There is a lacking of empirical research, a major limitations, that refraining this paper from giving a stronger ground on the findings. As Saunders, Lewis and Thornhill (2007) have claimed that the combination of both qualitative and quantitative methods provides strong ground on any principle; quantitative research has to be done to enlighten the findings. On top of that, Uppsala Model itself has limitations, as this model merely unable to elucidate the Internationalization challenges of modern era.

Additionally, further research can be done to identify the impact of MNE in its new location's economy, possible transection cost due to economic exchange, and its impact of local indigenous firms.

\section{References}

Bhagwati, J. (2004). In Defence of Globalization. New York: Oxford University Press Inc.

Blomsterm, A., \& Sharma, D. D. (2003). The Three decades of Research on Internationalization of Process of Firms. In A. Blomsterm \& D. D. Sharma (Eds.), Learning in the Internationalisation Process of Firms (1st ed., pp. 16-35). Gloucestershire: Edward Elgar publishing limited. 
Brewer, P. A. (2007). Operationalizing Psychic Distance: A Revised Approach. Journal of International Marketing, 15(1). http://dx.doi.org/10.1509/jimk.15.1.044

Casson, M. (2000). Economics of International Business. Gloucestershire: Edward Elgar Publishing Limited. http://dx.doi.org/10.4337/9781843767015

Dicken, P. (2003). Global Shift: Reshaping the Global Economic Map in the $21^{\text {st }}$ century (4th ed.). London: Saga Publications.

Doz, Y. L. (1978). Managing Manufacturing Rationalization within Multinational Companies. Columbia Journal of World Business, 13(3).

Dunning, J. H. (1993a). Multinational Enterprises and the Global Economy. Boston: Addition Wesley.

Dunning, J. H. (1993b). Assessing the Costs and Benefits of Foreign Direct Investment: Some Theatrical Consideration. In P. Artisien-Maksimenko (Ed.), Multinationals in Eastern Europe (pp. 10-57). London: Macmillan Press Ltd.

Dunning, J. H. (2000). Regions, Globalization and Knowledge Based Economy: The Issue Related. In J. H. Dunning (Ed.), Regions, Globalization and Knowledge Based Economy (pp. 7-41). New York: Oxford University Press Inc.

Dunning, J. H. (2001). The Eclectic (OLI) Paradigm of International Production: Past, Present and Future. International Journal of the Economics of Business, 8(2). http://dx.doi.org/10.1080/13571510110051441

Forsgren, M., \& Hagström, P. (n.d.). Ignorant Internationalization? The Uppsala Model and Internationalization Patterns for Internet-Related Firms. Uppsala: Uppsala University. [Online] Available: http://www.snee.org/filer/papers/361.pdf

Guo, S., \& Upathamwaranon, P. (2008). The Internationalization Process of Toyota in Europe: From the Perspectives of Entry Mode and Network Structure. Västerå: Mälardalen University. [Online] Available: http://mdh.diva-portal.org/smash/get/diva2:344/FULLTEXT01

Hessels, J. (2008). Overcoming Resource-Constraints through Internationalization? An Empirical Analysis of European SMEs. Zoetermeer: EIM Business and Policy Research. [Online]

Available: http://www.entrepreneurship-sme.eu/sys/cftags/assetnow/design/widgets/site/ctm_getFile.cf m?file=H200806.pdf\&perId=0

Hsu, C. C., \& Pereira, A. (2008). Internationalization and performance: The moderating effects of organizational learning. Omega, 36(2). http://dx.doi.org/10.1016/j.omega.2006.06.004

Johanson, J., \& Vahlne, J. E. (2009). The Uppsala internationalization process model revisited: From liability of foreignness to liability of outsidership. Journal of International Business Studies, 40(4). http://dx.doi.org/10.1057/jibs.2009.24 


\section{Macrothink}

Business and Management Horizons

ISSN 2326-0297

2015, Vol. 3, No. 1

Maghrabi, A. S. (2006). Compelling Claims on Multinational Corporate Conduct. Journal of American Academy of Business, 8(2).

Medcof, J. W., \& Chatoorgoon, R. (2006). Pharmaceutical R\&D in China by Western MNC's. [Online] Available:

http://www.iamot.org/conference/index.php/ocs/10/paper/viewFile/1362/610

Minter, S. (2009). The Promise of India. Industry Week, 258(2).

Modelski, G. (1972). Multinational Business A Global Perspective. In G. Modelski (Ed.), Multinational Corporations and World Order (1st ed., pp. 5-30). California: Saga Publications. http://dx.doi.org/10.2307/3013607

Navaretti et al. (2005). Multinationals: heroes or villains of the global economy? London: Centre Piece. [Online] Available: http://cep.lse.ac.uk/centrepiece/v10i1/venables.pdf

Needle, D. (2010). Business in Context an Introduction Business and its Environment. Singapore: Cengage Learning.

Saunders, M., Lewis, P., \& Thornhill, A. (2007). Research Method for Business Students (4th ed.). Essex: Pearson Education Limited.

Toyota. (n.d.). Discover Toyota's Heritage 70+years of history. [Online] Available: http://www.toyota-europe.com/experience/the_company/toyota-in-europe.aspx

Vernon, R. (1979). The Product Cycle Hypothesis in New International Environment. Oxford $\begin{array}{lllll}\text { Bulletin of } \quad \text { Economics } & \text { Statistics, } & \text { 41(4). }\end{array}$ http://dx.doi.org/10.1111/j.1468-0084.1979.mp41004002.x

Yeung, H. W. Y. (2009). Transnational Corporations, Global Production Networks, and Urban and Regional Development: A Geographer's Perspective on Multinational Enterprises and the Global Economy. Growth \& Change, 40(2). http://dx.doi.org/10.1111/j.1468-2257.2009.00473.x

\section{Copyright Disclaimer}

Copyright for this article is retained by the author(s), with first publication rights granted to the journal.

This is an open-access article distributed under the terms and conditions of the Creative Commons Attribution license (http://creativecommons.org/licenses/by/3.0/). 